
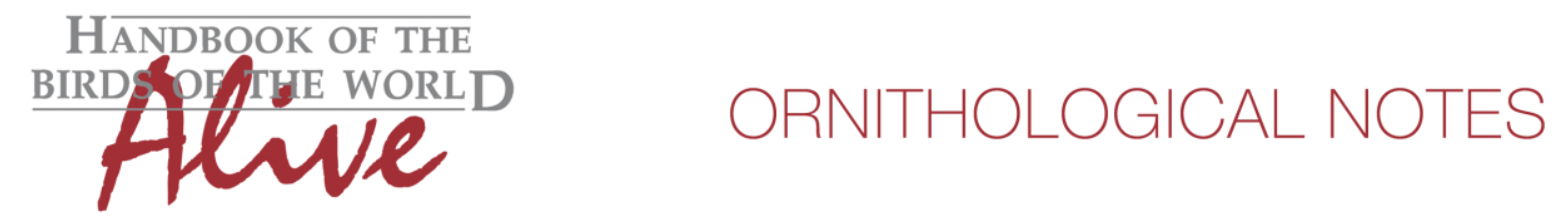

\title{
Notes on the vocalizations of White-lined Honeyeater (Meliphaga albilineata) and Kimberley Honeyeater (Meliphaga fordiana)
}

\author{
Peter Boesman
}

In the following we briefly analyze and compare voice of the different races of White-lined Honeyeater (Meliphaga albilineata) and Kimberley Honeyeater (Meliphaga fordiana). We also try to quantify the extent of any vocal differences using the criteria proposed by Tobias et al. (2010), as a support for taxonomic review. We have made use of sound recordings available on-line from Xeno Canto (XC).

A thorough vocal analysis (Miller et al. 2014) led to the conclusion that there are large differences between the songs of the species. Specifically, the White-lined Honeyeater sings songs with longer and more tremulous notes, longer pauses between notes, and a higher minimum frequency. The authors don't provide measurement data of the vocal parameters, but immediately switch to principal components, which makes interpretation and application of Tobias criteria somewhat problematic.

Many subspecies are identifiable by voice, even looking at single sound parameters, let alone several variables combined. The fact songs are recognizable is thus not enough proof for species status. I have therefore done a quick analysis on the (few) available XC recordings to have also some quantification of the extent of vocal differences based on single sound parameters.

\begin{tabular}{lcl} 
& White-lined Honeyeater $(\mathrm{n}=5)$ & Kimberley Honeyeater $(\mathrm{n}=3)$ \\
\hline min. pause & $0.2-0.79 \mathrm{~s}$ & $0.44-0.60 \mathrm{~s}$ \\
max. pause & $0.96-4.7 \mathrm{~s}$ & $0.6-2.8 \mathrm{~s}$ \\
min. freq. & $1520-2000 \mathrm{~Hz}$ & $1100-1420 \mathrm{~Hz}$ \\
max. freq. & $2900-3700 \mathrm{~Hz}$ & $3300-3400 \mathrm{~Hz}$ \\
min. note length & $0.12-0.43 \mathrm{~s}$ & $0.08-0.14 \mathrm{~s}$ \\
max. note length & $0.28-0.45 \mathrm{~s}$ & $0.20-0.27 \mathrm{~s}$ \\
max. freq. range single note & $900-1700 \mathrm{~Hz}$ & $1700-1800 \mathrm{~Hz}$ \\
max. freq. range song & $1000-2100 \mathrm{~Hz}$ & $2000-2200 \mathrm{~Hz}$ \\
\#notes per phrase & $1-7$ & $3-6$ \\
average pace & $0.7-1.7 \mathrm{~s} / \mathrm{note}$ & $0.32-0.55 \mathrm{~s} / \mathrm{note}$
\end{tabular}

The above data confirm that White-lined Honey-eater differs mainly by the slower pace (score 2-3), the lack of short notes which have a high frequency range (score 2 ), the presence of long tremulous notes (score 2) and slightly higher minimum frequencies (score 1-2) (Fig. 1).

If we apply Tobias criteria on this admittedly small set of recordings, this would lead to a total vocal score of 4-5. 


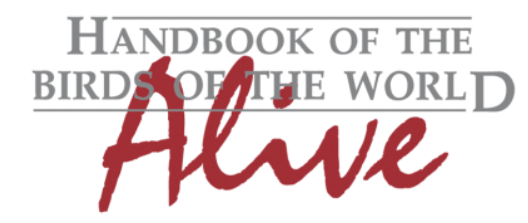

\section{ORNITHOLOGICAL NOTES}
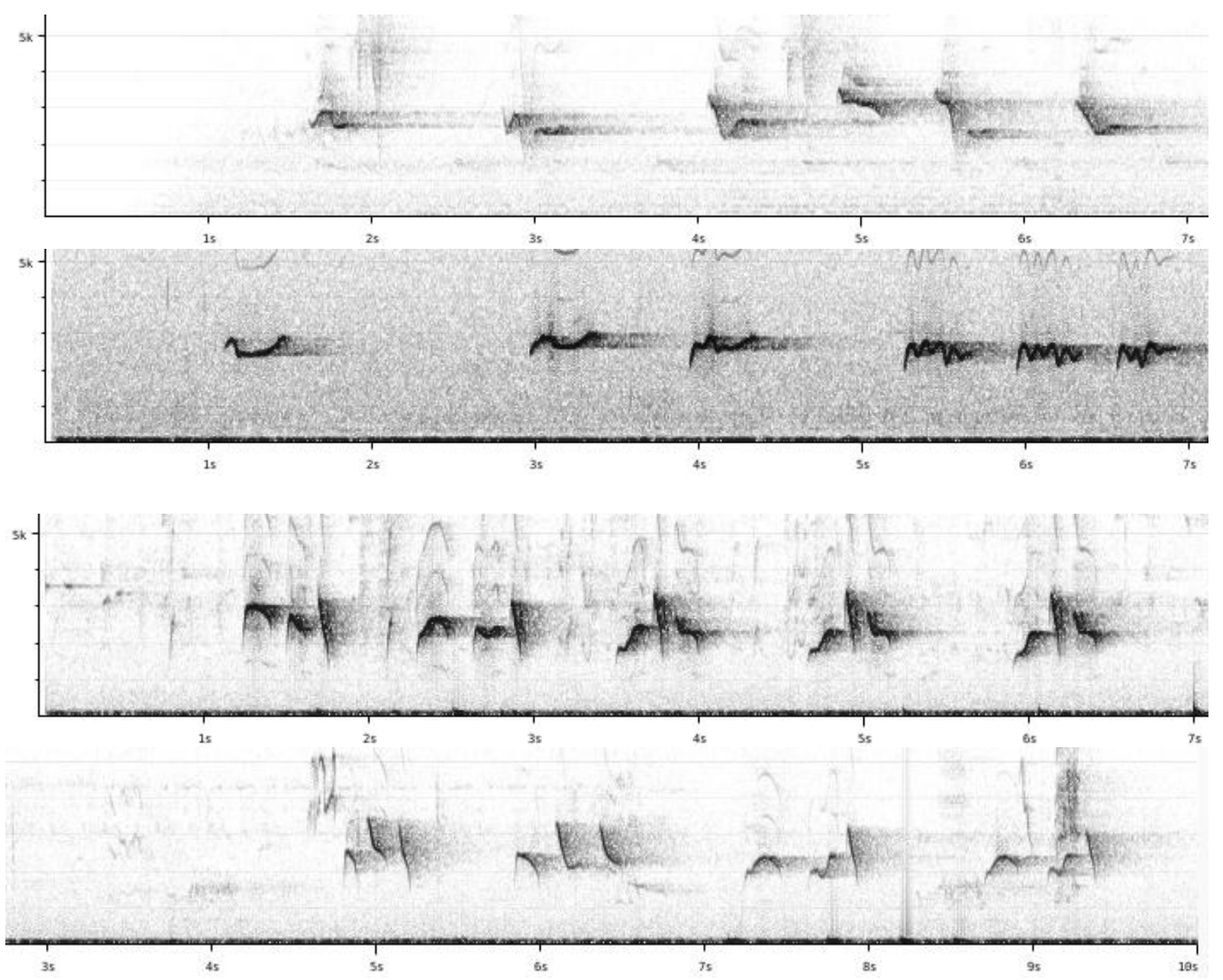

Figure 1: song of White-lined Honeyeater (top two) and Kimberley Honeyeater (bottom two)

This note was finalized on 17th September 2015, using sound recordings available on-line at that moment. We would like to thank in particular the sound recordists who placed their recordings for these species on XC: Eliot Miller and Marc Anderson.

\section{References}

Miller, E.T. and Wagner, S.K. (2014). The vocalisations and species status of the White-lined and Kimberley Honeyeaters. Emu 114(2): 116-120.

Tobias, J.A., Seddon, N., Spottiswoode, C.N., Pilgrim, J.D., Fishpool, L.D.C. \& Collar, N.J. (2010). Quantitative criteria for species delimitation. Ibis 152(4): 724-746.

\section{Recommended citation}

Boesman, P. (2016). Notes on the vocalizations of White-lined Honeyeater (Meliphaga albilineata) and Kimberley Honeyeater (Meliphaga fordiana). HBW Alive Ornithological Note 153. In: Handbook of the Birds of the World Alive. Lynx Edicions, Barcelona. (retrieved from http://www.hbw.com/node/932083 on 17 August 2016). 